\title{
Frequency of pathogenic and enteroadherent Escherichia coli in patients with inflammatory bowel disease and controls
}

Department of Medical Microbiology,

Academic Medical Centre, Meibergdreef 9, $1105 \mathrm{AZ}$

Amsterdam, The

Netherlands

C Schultsz

M Moussa

$\mathrm{R}$ van Ketel

J Dankert

Department of

Gastroenterology

G N J Tytgat

Correspondence to:

Dr Schultsz; email

c.schultsz@amc.uva.nl

Accepted for publication 13 May 1997

\begin{abstract}
Aims-To determine whether inflammatory bowel disease (IBD) is associated with pathogenic or enteroadherent $E s$ cherichia coli.

Methods-A least two stool specimens and one rectal biopsy were taken from 30 patients with IBD and from 20 controls. A large number of $E$ coli-like colonies cultured from each stool sample and biopsy was tested, using DNA probes, for the presence of genes encoding shiga-like toxins, invasiveness, attachmenteffacement and the ability to adhere to HEp-2 cells. Similarity among isolates from stool samples and rectal biopsies was determined by random amplified polymorphic DNA (RAPD) analysis.

Results-Enterohaemorrhagic and enteroinvasive $E$ coli were not found in samples from either patients or controls. No significant difference in the detection rate of enteroadherent $E$ coli between patients and controls was found. Rectal biopsies from 11 of 28 patients with IBD and 4 of 18 controls contained $E$ coli, which hybridised with probes for detection of genes encoding diffuse adherence to HEp-2 cells, or encoding $P$-pili $(p=0.2)$. Enteroadherent $E$ coli isolated from two or three stool specimens from the same patient or control appeared to be identical by RAPD analysis, and are considered to be residents in the colon. Probe positive isolates obtained from stool specimens and corresponding rectal biopsies were always identical on RAPD analysis.
\end{abstract}

Conclusions-E coli strains possessing adherence factors reside in the large intestine and adhere to the rectal mucosa, irrespective of the presence of colitis. (F Clin Pathol 1997;50:573-579)

Keywords: enteroadherent Escherichia coli; inflammatory bowel disease; resident flora

Although the aetiology of inflammatory bowel disease (IBD) is not known, evidence from a variety of animal models of intestinal inflammation suggests that the presence of bacteria is required to sustain the inflammatory reaction. ${ }^{1}$ Pathogenic Escherichia coli strains, present in the colon, may play a role in the pathogenesis of IBD. In several studies, $E$ coli possessing properties such as Shiga-like toxin production, ${ }^{23}$ hydrophobicity, ${ }^{4}$ adhesiveness, ${ }^{56}$ or the capac- ity to bind to matrix proteins ${ }^{7}$ were present in a higher proportion of patients with IBD than in controls without colitis.

Bacterial adherence to the epithelial surface or to the mucous layer covering the epithelium is considered a prerequisite for persistence of bacteria in the gut, including pathogenic bacteria such as Vibrio cholerae and enterotoxigenic $E$ coli. ${ }^{8}$ Among the various adhesins of $E$ coli mediating binding to epithelial cells, P-pili have been shown to be associated with persistence of $E$ coli in the colon. ${ }^{9}{ }^{10} E$ coli strains with the property to adhere to $\mathrm{HEp}-2$ cells and intestinal epithelial cells in vitro have been associated with diarrhoea in studies from different geographic areas. ${ }^{11}$ Such $E$ coli strains are designated enteroadherent $E$ coli, showing either localised adherence, diffuse adherence (DAEC), or aggregative adherence (EAggEC) to HEp-2 cells. The localised type of adherence is characteristic for the classic enteropathogenic $E$ coli (EPEC) and is expressed in conjunction with the capacity to produce typical attaching-effacing lesions in various epithelial cells. ${ }^{12}$ Although enteroadherent $E$ coli are known to produce adhesins $\mathrm{s}^{11}{ }^{12}$ and are thought to cause diarrhoea, the pathogenic nature of DAEC and EAggEC is not known and data obtained in volunteer studies were not conclusive as to whether such strains have pathogenic properties. ${ }^{11}$

$E$ coli strains isolated from faecal specimens or rectal biopsies, expressing increased adhesion to buccal epithelial cells, HEp-2 cells or to HT-29 cells, have been cultured more frequently among patients with IBD than controls. ${ }^{5-7}$ Although it has been suggested that $E$ coli from IBD patients shows more ability to adhere, results from studies on adherence are conflicting. ${ }^{13}{ }^{14}$ In the majority of these studies, strains isolated from either stool specimens or rectal biopsies were studied, and $E$ coli adherence was determined only phenotypically. Test results could vary because of differences between the type of epithelial cells to which the bacteria were allowed to adhere, the duration of the incubation period, the number of isolates tested from each patient, the bacterial growth media used, and observational differences. The variability of these conditions will be reduced if specific methods to detect genes encoding adherence factors in conjunction with phenotypic assays are used. Although only strains will be detected for which the particular adherence factor has been characterised, this approach will yield relevant 
information about the significance of such adherent $E$ coli in the gastrointestinal tract of patients with IBD.

To study whether the presence of pathogenic or enteroadherent $E$ coli is associated with IBD, we compared the prevalences of pathogenic and enteroadherent $E$ coli in patients with and without IBD. For this purpose, large numbers of isolates from stool specimens and corresponding rectal biopsies were tested using seven DNA probes for specific detection of genes encoding different virulence factors and adhesins. In addition, phenotypic expression of genes encoding adherence was assessed by using the HEp-2 cell adhesion assay. Finally, to determine whether isolates from stool specimens and corresponding rectal biopsies were related, subsets of isolates were characterised by using random amplified polymorphic DNA (RAPD) analysis.

\section{Materials and methods}

\section{PATIENTS AND SAMPLE COLLECTION}

Patients who visited our department of gastroenterology for endoscopy were included in the study. Patients were enrolled if they had active (newly diagnosed or relapse) ulcerative colitis or Crohn's disease. Diagnosis was confirmed by endoscopy and histology. Only patients with a definite diagnosis of ulcerative colitis or Crohn's disease were included.

From each patient, stool specimens were collected on the day of presentation, two to eight weeks later and, whenever possible, approximately three months later. In addition, from each patient a rectal biopsy was performed at endoscopy on the day of presentation. From patients with Crohn's disease, an additional biopsy from an ulcerated area was done if the rectum appeared normal.

Control were patients who required endoscopy for reasons other than IBD (for example, irritable bowel syndrome) and who did not complain of diarrhoea. Patients were enrolled as controls if results from endoscopy and histology were normal. From each control, a stool specimen and a rectal biopsy were collected on the day of endoscopy. A second stool specimen was collected two to eight weeks later.

Patients and controls were excluded if they had taken antimicrobial therapy during the previous six weeks, if they had visited tropical areas during the previous year, or if they had a history of colon carcinoma. All stool specimens were collected before preparation for endoscopy.

EXAMINATION OF STOOL SPECIMENS

Stool specimens were stored at $4^{\circ} \mathrm{C}$ and processed within 24 hours after collection. All specimens were examined for Salmonella, Shigella, Yersinia, and Campylobacter spp using standard identification methods. Stool specimens collected on the day of presentation were also cultured for Clostridium difficile and examined for amoeba, ova, and cysts by direct microscopical examination and after concentration (modified Ridley method). All speci- mens were tested for the presence of $C$ difficile toxin by tissue culture assay.

For detection of pathogenic and enteroadherent $E$ coli, a suspension of a stool specimen was made with an equal volume of phosphate buffered saline (PBS, pH 7.2). After serial 10 -fold dilution, $50 \mu \mathrm{l}$ from each dilution was plated onto a MacConkey agar plate. After growth at $37^{\circ} \mathrm{C}$ for 18 hours, the plate containing approximately 100-300 separate colonies was selected and replica plated onto six nylon membranes (Hybond-N; Amersham Nederland, Hertagensbosch, The Netherlands). Colonies on each membrane were grown on nutrient agar plates for seven hours, then lysed, denatured, and fixed to the membrane, essentially as described by Sambrook et al. ${ }^{15}$

\section{EXAMINATION OF RECTAL BIOPSIES}

Rectal biopsies were immediately wrapped in parafilm, snap frozen in liquid nitrogen, and stored at $-70^{\circ} \mathrm{C}$. For examination, biopsies were gently washed twice in PBS, homogenised in $1 \mathrm{ml}$ of Trypticase Soy Broth (TSB) using a Potter apparatus and incubated at $37^{\circ} \mathrm{C}$ for 18 hours. After serial 10-fold dilution, $50 \mu$ from each dilution was plated onto a MacConkey agar plate, replica plated, and further treated as the stool specimens.

From MacConkey agar plates showing growth of $E$ coli-like bacteria, 10 colonies were randomly picked and identified biochemically as $E$ coli using standard identification methods. These colonies were inoculated on agar slants and stored.

\section{HAEMOLYSIN PRODUCTION}

Each stored $E$ coli isolated from rectal biopsies was inoculated onto a sheep blood ( $5 \% \mathrm{vol} / \mathrm{vol})$ agar plate and incubated at $37^{\circ} \mathrm{C}$ for 18 hours. Isolates were considered haemolytic if a bright zone was visible surrounding each colony.

\section{DETECTION OF PATHOGENIC AND ADHERENT} E COLI WITH DNA PROBES

Nylon membranes containing approximately 100-300 colonies were hybridised under stringent conditions with six digoxigenin (DIG) labelled polynucleotide DNA probes for detection of genes encoding Shiga-like toxin production (SLT1, SLT2; enterohaemorrhagic $E$ coli, EHEC), the capacity to produce attachingeffacing lesions in epithelial cells (eae; attaching-effacing $E$ coli, AEEC), enteroinvasiveness (enteroinvasive $E$ coli, EIEC), diffuse adherence to HEp-2 cells (daaC, DAEC), and aggregative adherence to $\mathrm{HEp}-2$ cells (AA, EAggEC) (table 1). Probes were labelled by random primer method and hybrids were detected by alkaline phosphatase labelled antiDIG antibody, both according to the instruction in the DIG DNA labelling and detection kit (Boehringer Mannheim BV, Almere, The Netherlands). Control strains were included in each hybridisation reaction (table 1). Probes and control strains were kindly provided by $B$ Rowe, Central Public Health Laboratory, London, UK.

From the stored $E$ coli isolates obtained from each rectal biopsy, a suspension in PBS was 
Table 1 DNA probes used for detection of pathogenic and enteroadherent $E$ coli

\begin{tabular}{llll}
\hline & Plasmid/probe & Control strain & Reference \\
\hline Shiga-like toxin 1 producing $E$ coli & NTP 705 & E3787 & 16 \\
Shiga-like toxin 2 producing $E$ coli & pDEP 28 & E32511 & 16 \\
Diffusely adhering $E$ coli & pSLM852 & E72540 & 17 \\
Aggregatively adhering $E$ coli & pCVD432 & E69187 & 18 \\
Attaching-effacing $E$ coli & pCVD434 & E674/72 & 19 \\
Enteroinvasive $E$ coli & H1 & E12632/0 & 20 \\
P-piliated $E$ coli & PCR-generated & AD110 & 21 \\
\hline
\end{tabular}

^Cloned probe fragments were cut from plasmids after digestion with the appropriate restriction enzymes.

spotted onto nylon membranes, grown for seven hours, lysed, denatured, and fixed to the membrane, and hybridised additionally with a DIG labelled PCR generated polynucleotide probe for detection of pap related sequences encoding P-pili (table 1).

\section{ADHESION TO HEP-2 CELLS}

All probe positive isolates from stool samples and rectal biopsies were tested for adherence to HEp- 2 cells. In addition, 10 probe negative $E$ coli strains cultured from each rectal biopsy were grown overnight in nutrient broth containing $1 \% \mathrm{~d}$-mannose (wt/vol), then equal volumes were pooled and mixed, and $10 \mu \mathrm{l}$ from this pool was added to the HEp- 2 cells.

Adhesion of $E$ coli to HEp-2 cells was assessed in a six hour assay as described by Scotland et al. ${ }^{22}$ Briefly, HEp-2 cells were maintained in Dulbecco's Minimum Essential Medium (DMEM; Gibco Europe BV, Breda, The Netherlands) containing $10 \%$ ( $\mathrm{vol} / \mathrm{vol})$ fetal calf serum, at $37^{\circ} \mathrm{C}$ in $5 \% \mathrm{CO}_{2}$ atmosphere. Cells were transferred to tissue culture plates with 24 wells containing glass coverslips and grown to semiconfluent monolayers. After replacement of the medium with fresh DMEM with $1 \% \mathrm{~d}$-mannose, cells were inoculated with $10 \mu$ of each probe positive $E$ coli isolate grown overnight in nutrient broth containing $1 \%$ $\mathrm{d}$-mannose or $10 \mu \mathrm{l}$ of pooled probe negative isolates. Bacteria were allowed to attach for three hours. The cells were washed three times with Dulbecco's PBS (DPBS, Gibco) to remove non-adherent bacteria and incubated for another three hours. Cells were washed again, fixed with $1 \%$ (vol/vol) paraformaldehyde and $0.1 \%$ (vol/vol) glutaraldehyde in DPBS for at least 30 minutes and stained with diluted crystal violet. Bacteria were considered adherent if more than 10 bacteria per cell were adhering to at least $40 \%$ of the cells. In general, 100 to 200 cells were counted. The pattern of adherence (localised, diffuse or aggregative) was also recorded.

CHARACTERISATION OF ISOLATES BY RAPD

Sets of isolates obtained from stool specimens and corresponding rectal biopsies as well as from consecutive stool specimens, were characterised using RAPD.

Bacteria were grown overnight at $37^{\circ} \mathrm{C}$ on sheep blood agar plates. Bacteria were washed in PBS and suspended in PBS to a concentration of $3 \times 10^{8}$ bacteria $/ \mathrm{ml}$ using MacFarlands opacity standard. After heating for 10 minutes, an equal volume of chloroform was added to the suspensions. The lysates were mixed and centrifuged at $12000 \times g$ for 10 minutes in an Eppendorf centrifuge. Two different PCRs were performed on the pellets to compare the DNA contents of bacteria.

PCR targeting repetitive intergenic DNA sequences Primers ERIC1R (3'-CACTTAGGGGTCC TCGAATGTA-5') and ERIC2 (5'-AAGTAA AGTGACTGGGGTGAGCG-3') were used as described by Versalovic et al. ${ }^{23}$. Briefly, the amplication procedure was performed in a final volume of $50 \mu \mathrm{l}$. The reaction mixture contained $10 \mathrm{mM}$ Tris $\mathrm{HCl}$ (pH 8.3), $50 \mathrm{mM}$ $\mathrm{KCl}, 25 \mathrm{mM} \mathrm{MgCl}, 100 \mu \mathrm{M}$ of each deoxyribonucleotide, $100 \mathrm{ng}$ of each oligonucleotide, and 1.25 U Taq polymerase (Amplitaq, PerkinElmer, Gouda, The Netherlands), to which $10 \mu \mathrm{l}$ of the bacterial suspension was added. The mixtures were processed in a programmable DNA thermal cycler (Perkin-Elmer) and subjected to 35 cycles of amplification. One cycle consisted of one minute at $95^{\circ} \mathrm{C}$, one minute at $52^{\circ} \mathrm{C}$, and two minutes at $72^{\circ} \mathrm{C}$.

Ten microlitres of amplified sample were electrophoresed in a $1 \%$ agarose gel with a molecular mass marker and stained with ethidium bromide. Isolates to be compared were processed simultaneously and electrophoresed on the same agarose gel.

\section{PCR using an arbitrary primer}

PCR was performed using arbitrary primer $\mathrm{TT}_{3}$ (5'-GGCGAGGAGCG-3'). Conditions were as described above except that $1 \mu \mathrm{g}$ of oligonucleotide was used. PCR started with two cycles consisting of five minutes at $95^{\circ} \mathrm{C}$, five minutes at $40^{\circ} \mathrm{C}$, and five minutes at $72^{\circ} \mathrm{C}$, followed by 33 cycles consisting of one minute at $95^{\circ} \mathrm{C}$, one minute at $40^{\circ} \mathrm{C}$, and two minutes at $72^{\circ} \mathrm{C}$.

\section{STATISTICAL ANALYSIS}

Differences between groups were calculated by using Fisher's exact or $\chi^{2}$ test when appropriate.

\section{Results}

In total, 61 stool specimens from 30 IBD patients (20 patients with ulcerative colitis, 10 patients with Crohn's disease), and 28 stool specimens from 20 controls were cultured (table 2). Rectal biopsies were also collected, except from two patients with ulcerative colitis, and two controls.

Salmonella enteritidis was found in one patient with ulcerative colitis, toxin producing $C$ difficile in one patient with ulcerative colitis, and Plesiomonas shigelloides in one patient with Crohn's disease. One control had both Campylobacter jejuni and Giardia lamblia. No other enteropathogens were detected.

DETECTION OF PATHOGENIC AND ADHERENT E COLI WITH DNA PROBES

Five of $61(8 \%)$ stool samples from 30 patients with IBD yielded no growth after culture on MacConkey agar plates whereas all 28 stool samples from 20 controls showed growth of coliform bacteria. The detection rate of patho- 
Table 2 Characteristics of patient and control groups

\begin{tabular}{|c|c|c|c|}
\hline & \multicolumn{2}{|l|}{ IBD patients } & \multirow[b]{2}{*}{$\begin{array}{l}\text { Controls } \\
(n=20)\end{array}$} \\
\hline & $\begin{array}{l}\text { Ulcerative colitis } \\
(n=20)\end{array}$ & $\begin{array}{l}\text { Crohn's disease } \\
(n=10)\end{array}$ & \\
\hline Median age (years) & 32 & 25 & 42 \\
\hline Male/female & $12 / 8$ & $1 / 9$ & $4 / 16$ \\
\hline $\begin{array}{l}\text { Median duration of disease } \\
\text { (years) }\end{array}$ & 5 & 3.5 & NA \\
\hline Number of patients studied with: & & & \\
\hline 1 stool specimen & 4 & 4 & 12 \\
\hline 2 stool specimens & 9 & 4 & 8 \\
\hline 3 stool specimens & 7 & 2 & NA \\
\hline Total number of stool specimens & 43 & 18 & 28 \\
\hline Number of rectal biopsies & 18 & 10 & 18 \\
\hline
\end{tabular}

NA, not applicable.

Table 3 The frequency of pathogenic and adherent $E$ coli in stool samples and rectal biopsies from 20 patients with ulcerative colitis, 10 patients with Crohn's disease, and 20 controls, as detected by using seven specific DNA probes

\begin{tabular}{|c|c|c|c|c|c|c|}
\hline \multirow[b]{2}{*}{$E$ coli } & \multicolumn{2}{|c|}{ Ulcerative colitis } & \multicolumn{2}{|c|}{ Crohn's disease } & \multicolumn{2}{|l|}{ Controls } \\
\hline & $\begin{array}{l}\text { Stool } \\
(n=20)\end{array}$ & $\begin{array}{l}\text { Biopsy } \\
(n=18)\end{array}$ & $\begin{array}{l}\text { Stool } \\
(n=10)\end{array}$ & $\begin{array}{l}\text { Biopsy } \\
(n=10)\end{array}$ & $\begin{array}{l}\text { Stool } \\
(n=20)\end{array}$ & $\begin{array}{l}\text { Biopsy } \\
(n=18)\end{array}$ \\
\hline EHEC $^{\star}$ & 0 & 0 & 0 & 0 & 0 & 0 \\
\hline AEEC & 0 & 0 & $1(10)$ & $1(10) \dagger$ & $1(5)$ & $1(6)$ \\
\hline EIEC & 0 & 0 & 0 & 0 & 0 & 0 \\
\hline DAEC & $4(20) \ddagger$ & $3(17) 99$ & 0 & 0 & $4(20)$ & $1(6)$ \\
\hline EAggEC & $2(10) \ddagger$ & $1(6) 5$ & $1(10$ & $1(10)$ & 0 & 0 \\
\hline P-piliated & ND & $6(33) \pi$ & ND & $2(20) t$ & ND & $2(10)$ \\
\hline Total & $4(20)$ & $8(44)$ & $2(20)$ & $3(33)$ & $5(25)$ & $4(22)$ \\
\hline
\end{tabular}

${ }^{\star}$ Results after hybridisation with probes for detection of SLT1 and SLT2 encoding genes.

†From one biopsy strains were positive with both eae and P-pili probes; $\ddagger$ Two patients carried both DAEC and AAEC probe positive strains in the first stool sample; §From one biopsy strains were positive with both DAEC and AAEC probes; ๆFrom one biopsy strains were positive with both DAEC and P-pili probes.

EHEC, enterohaemorrhagic $E$ coli; AEEC, attaching-effacing $E$ coli; EIEC, enteroinvasive $E$ coli DAEC, diffusely adhering $E$ coli; EAggEC, aggregatively adhering $E$ coli; ND, not determined.

genic or adherent $E$ coli in stool specimens from patients and controls was similar (table 3 ). DAEC was the most commonly found $E$ coli. No EHEC or EIEC were detected. In case stool samples were probe positive, the majority of the 100-200 colonies tested ( $>80 \%$ ) after replication on a nylon membrane, hybridised with the respective DNA probe. Membranes from three stool specimens, one from a patient with ulcerative colitis and two from controls, contained 10 or fewer $(<10 \%)$ positive colonies that hybridised with the daaC probe. Patients and controls who harboured probe positive isolates in their first stool specimen, generally harboured such isolates in their second and third stool specimen when available (fig 1).

Eight of $28(29 \%)$ rectal biopsies from 28 patients with IBD and six of 18 (33\%) biopsies from 18 controls yielded no growth of coliform bacteria after culture in TSB and subculture on MacConkey agar. Negative culture results were not related to intestinal lavage before endoscopy. Probe positive $E$ coli cultured from seven of the remaining 32 rectal biopsies were either DAEC, EAggEC or AEEC. EHEC or EIEC were absent (table 3 ). The finding of probe positive isolates from rectal biopsies was strongly related to the presence of such strains in the corresponding stool sample (fig 1).

Strains from rectal biopsies were additionally tested for the presence of genes encoding
P-pili. Strains from biopsies obtained from patients with IBD more often hybridised with the pap probe than strains obtained from biopsies from controls (table 3 ), but this difference was not statistically significant $(p=0.27)$.

\section{ADHESION TO HEP-2 CELLS}

From the seven rectal biopsies and corresponding stool samples with probe positive $E$ coli strains from both patients and controls, strains adhered to HEp-2 cells and showed the pattern of adherence as predicted by the probe to which they hybridised in four cases. Strains from one biopsy and corresponding stool sample, positive with the daaC probe, did not show adhesion to HEp-2 cells. None of the pools of probe negative isolates from rectal biopsies showed adhesion to HEp-2 cells. daaC probe positive isolates obtained from stool samples from two controls but not from their corresponding rectal biopsies, showed diffuse adhesion to HEp-2 cells. Probe positive strains from two biopsies (strains from one biopsy were positive with both the daaC and $\mathrm{AA}$ probes, strains from the other biopsy were positive with the eae probe) and probe negative strains from one biopsy caused detachment of the cells from the glass cover slips, which made it impossible to observe any pattern of adhesion.

\section{HAEMOLYSIN PRODUCTION}

Strains from seven biopsies produced haemolysin as detected on sheep blood agar plates. These seven were equally distributed among patients and controls. Haemolysin production was associated with the presence of genes encoding $P$-pili in four cases. All strains causing cell detachment in the HEp-2 cell adhesion assay produced haemolysin.

\section{RAPD ANALYSIS}

Using RAPD analysis, probe positive isolates from consecutive stool specimens from three patients were characterised. Isolates from consecutive samples from each patient appeared to be identical. As the median period between collection of first and second stool specimens from patients and controls was five weeks (range two to 28 weeks) and between collection of second and third stool specimens was seven weeks (range two to 16 weeks), identical strains isolated from consecutive stool specimens were considered to be residents in the colon.

RAPD analysis of probe positive $E$ coli strains obtained from a stool sample and corresponding rectal biopsy from one patient with ulcerative colitis showed that the isolates obtained from both materials were identical (fig 2).

In two controls, isolates in stool specimens were probe positive but only probe negative isolates were present in corresponding rectal biopsies. RAPD analysis of two probe positive isolates from stool and 10 probe negative isolates from the corresponding rectal biopsy of one of these controls showed that the probe positive and negative isolates were different. 


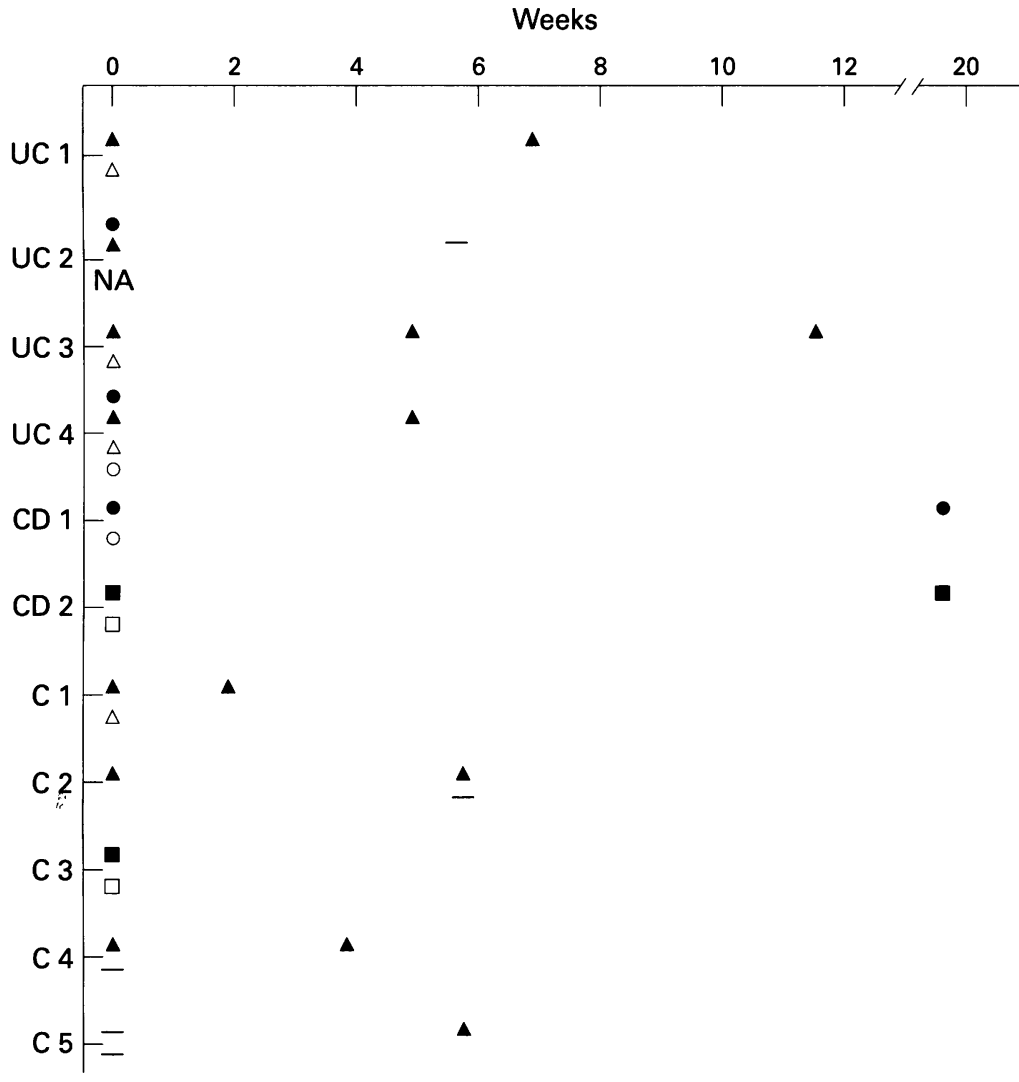

Figure 1 Detection of enteroadherent $E$ coli in stool samples and biopsies of four patients with ulcerative colitis (UC), two patients with Crohn's disease (CD), and five patients without inflammatory bowel disease $(C)$ in time. Triangles, strains positive after

hybridisation with a probe for detection of diffusely adhering $E$ coli; Circles, strains postive after hybridisation with a probe for detection of aggregatively adhering $E$ coli; Squares, strains positive after hybridisation with a probe for detection of attaching-effacing $E$ coli. Isolates obtained from stool samples are indicated by closed symbols, isolates obtained from rectal biopsies are indicated by open symbols. - No probe positive strains after hybridization with any of the probes; $N A$, not available.

\section{Discussion}

Various studies have addressed the hypothesis that virulent or adherent $E$ coli strains contribute to the pathogenesis of IBD in an unexplained manner. ${ }^{25-7} 131424$ No consistent data have been shown in such studies, in which a variety of tests was used and isolates from either stool specimens or rectal biopsies were examined. We used DNA probes to detect $E$ coli carrying genes encoding virulence factors and adhesins. In addition, a large number of colonies was tested from both stool specimens and corresponding rectal biopsies.

We did not observe significant differences in the prevalence of pathogenic or adherent $E$ coli in either stool specimens or rectal biopsies from patients with IBD and controls. No VTEC strains were detected by DNA hybridisation, in contrast with some studies ${ }^{2}$ but in concordance with others. ${ }^{14}$ Similarly, no enteroinvasive strains were found.

DAEC and P-piliated $E$ coli were the most frequently encountered probe positive $E$ coli. Similar to our results, Hartley et $a l^{13}$ found that the majority of adherent isolates from patients with IBD and controls showed diffuse adhesion to HEp-2 cells. The DNA probe we used detects genes shared by a family of genetically related adhesins mediating diffuse adhesion, the Dr family. ${ }^{25}{ }^{26}$ These adhesins include the Dr haemagglutinin, AFA I, AFA III, and

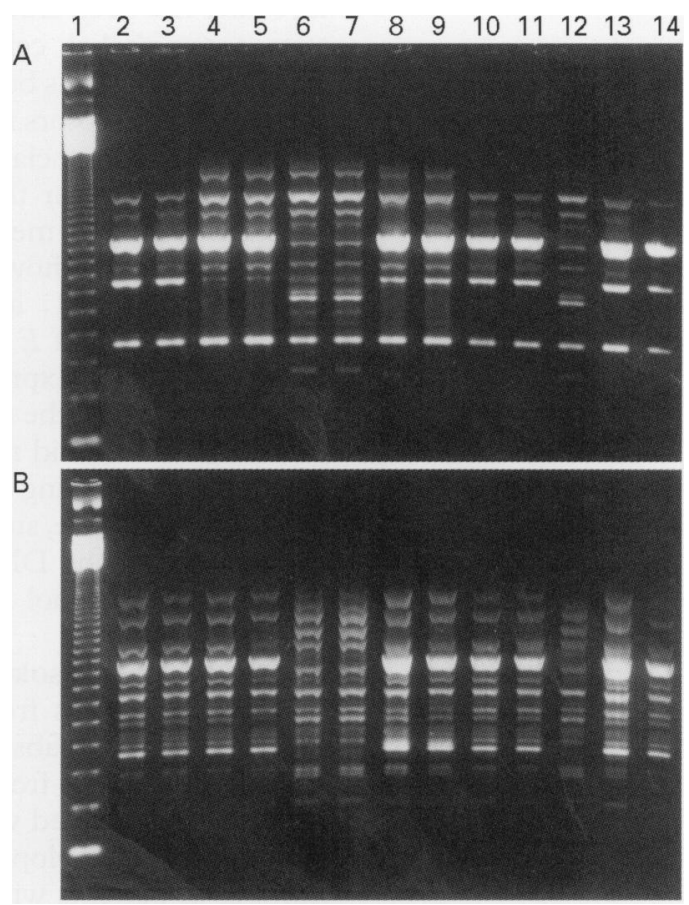

Figure 2 Results of RAPD analysis of isolates obtained from stool samples and a rectal biopsy of a patient with ulcerative colitis. (A) RAPD analysis performed with primers ERIC1R and ERIC2. (B) RAPD analysis performed with random primer TT3. Lane 1, molecular weight marker of 123 base pairs; Lanes 2-5, four probe positive isolates obtained from the first stool sample of $a$ patient with ulcerative colitis (patient 1829); Lanes 6 and 7, two probe negative isolates from the first stool sample of patient 1829; Lanes 8-11, four probe positive isolates obtained from the rectal biopsy from patient 1829 collected on the same day as the first stool sample; Lane 12, probe negative isolate obtained from the rectal biopsy from patient 1829; Lanes 13 and 14, two probe positive isolates from the second stool sample of patient 1829, obtained five weeks after the first stool sample.

F1845 adhesin, and recognise the $\operatorname{Dr}^{\mathrm{a}}$ blood group antigen as their receptor. ${ }^{27}$ This receptor is present on a large number of epithelial cells, including colonic epithelial cells. ${ }^{28}$ The pathogenic nature of DAEC has not been elucidated. ${ }^{11}$ Studies from different geographic areas show discordant results concerning their association with diarrhoea. In our study, identical DAEC, as shown by RAPD, could be detected in stool specimens from patients with IBD and controls with time, indicating that DAEC form a part of the resident flora of some adults, irrespective of the presence or absence of colitis (fig 1). Identical strains were also present on corresponding rectal biopsies, suggesting that these strains were truly adherent.

$E$ coli possessing P-pili adhere to colonic epithelial cells in vitro by binding to the Gal $\alpha 1-4 \mathrm{Gal} \beta$ containing receptor. ${ }^{29}$ Wold et a $l^{10}$ and Tullus $e t a l^{9}$ showed that P-pili expressing $E$ coli are residents in the colon at infancy, in contrast with transient strains that express P-pili less frequently. Although we only hybridised isolates obtained from single rectal biopsies with the probe for detection of pap related genes, we assume that the $\mathrm{P}$-pili encoding $E$ coli strains, isolated from rectal biopsies, are also resident strains.

The mechanisms underlying the association between resident bacteria and the mucosal sur- 
face have not been elucidated. Adhesion of bacteria to epithelial cells is thought to occur through interactions between bacterial adhesins and cellular receptors at the initial site of infection. Bacterial association with intestinal mucins may also occur through interactions with bacterial outer membrane components. ${ }^{30}$ Adlerberth et $a l^{\beta 1}$ showed that the Dr haemagglutinin, $P$, type 1 , and $S$ fimbrial adhesins mediate binding of $E$ coli to both colonic and ileal enterocytes. Expression of these adhesins may contribute to the establishment of $E$ coli in the intestine. We did not study the occurrence of $E$ coli possessing type 1 fimbriae or S fimbriae. Therefore, such strains may have been present among the DNA probe negative $E$ coli isolated from stool specimens and rectal biopsies.

EAggEC were isolated from stool samples and rectal biopsies from three of 28 patients with IBD but were absent in both stool samples and rectal biopsies from 20 controls. EAggEC have been associated with persistent diarrhoea in children in developing countries. ${ }^{32}{ }^{33}$ As the number of patients with EAggEC in our study was low, the association of EAggEC with IBD remains unclear.

$E$ coli isolates obtained from three rectal biopsies caused detachment of the HEp-2 cell monolayer on the glass coverslip. This phenomenon has also been described by other investigators and appeared to be related to haemolysin production. ${ }^{25}{ }^{34}$ Recently, it was shown that such strains are not associated with diarrhoea. ${ }^{35}$ An association with IBD is also not very likely as haemolysin producing strains were equally distributed among patients and controls in our study.

Although both patients and controls carried adherent $E$ coli in the large intestine at a similar rate, we cannot rule out the possibility that the mere presence of adherent bacteria in the colon, either $E$ coli or other species, contributed to the inflammation in patients with active IBD. Shen et $a l^{7}$ reported that in vitro adherence of $E$ coli from patients with colitis to matrix proteins was higher than from control strains. Bacteria may adhere to a damaged mucosal surface through increased exposure of receptors or through non-specific interactions when matrix proteins are exposed. ${ }^{36}$ Bacteria adhering to matrix proteins may thus contribute to an inflammatory response by exposing the mucosal immune system to bacterial antigens while bypassing the epithelial barrier. Adherence of some bacteria to epithelial cells has been shown to lead to the release of cytokines by the cells and to induce transepithelial migration of neutrophils. ${ }^{37}{ }^{38}$ Therefore, functional changes of the epithelial cells to which such bacteria have bound may also contribute to the inflammatory reaction seen in IBD. We have found no significant differences in the presence of true pathogenic $E$ coli in faecal samples or rectal biopsies from patients with IBD and controls. $E$ coli strains possessing $\mathrm{Dr}$ adhesins, and probably those possessing P-pili, are resident in the large intestine of some individuals and adhere to the rectal mucosa, irrespective of the presence or absence of colitis.
We thank P Fockens for assistance with sample collection and B de Wever and L van Alphen for assistance with RAPD analysis. We thank W van Est for technical assistance and M D de Jong We thank critically reviewing the manuscript.
for

1 Elson CO, Sartor RB, Tennyson GS, Riddell RH. Experimental models of inflammatory bowel disease. Gastroenterology 1995;109:1344-67.

2 Von Wulffen H, Russman H, Karch H, Meyer T, Bitzan T, Kohrt TC, et al. Verocytotoxin-producing Escherichia coli $\mathrm{O} 2: \mathrm{H} 5$ isolated from patients with ulcerative colitis. Lancet 1989;i:1449-59.

3 Ljungh A, Eriksson M, Eriksson O, Henter JI, Wadstrom T. Shiga-like toxin production and connective tissue protein binding of Escherichia coli from a patient with ulcerative binding of Escherichia coli from a patie

4 Burke DA, Axon ATR. Hydrophobic adhesin of E. coli in ulcerative colitis. Gut 1988;29:41-3.

5 Giaffer MH, Holdsworth CD, Duerden BI. Virulence properties of Escherichia coli strains isolated from patients with inflammatory bowel disease. Gut 1992;33:646-50.

6 Burke DA, Axon ATR. Adhesive Escherichia coli in inflammatory bowel disease and infective diarrhoea. $B M F$ 1988;297:102-4.

7 Shen W, Steinruck H, Ljungh A. Expression of binding of plasminogen, thrombosponding, vitronectin, and fibrinogen, and adhesive properties by Escherichia coli strains isogen, and adhesive properties by Escherichia coli strains iso-
lated from patients with colonic diseases. Gut 1995;36: 401-6.

8 Krogfelt K. Bacterial adhesion: genetics, biogenesis, and role in pathogenesis of fimbrial adhesins of Escherichia coli. Rev Infect Dis 1991;13:721-35.

9 Tullus K, Kuhn I, Orskov I, Orskov F, Mollby R. The importance of $\mathbf{P}$ and type 1 fimbriae for the persistence of Escherichia coli in the human gut. Epidemiol Infect 1992;108:415-21.

10 Wold AE, Caugant DA, Lidin-Janson G, De Man P, Svanborg C. Resident colonic Escherichia coli strains franborg C. Resident colonic Escherichia coli strains Dis 1992;165:46-52.

11 Savarino SJ. Enteroadherent Escherichia coli: a heterogeneous group of E. coli implicated as diarrhoeal pathogens. Trans $R$ Soc Trop Med Hyg 1993;87(suppl 3):49-53.

12 Donnenberg MS, Kaper JB. Enteropathogenic Escherichia coli. Infect Immun 1992;60:3953-61.

13 Hartley MG, Hudson MJ, Swarbrick ET, Gent AE, Hellier $M D$, Grace RH. Adhesive and hydrophobic properties of Escherichia coli from the rectal mucosa of patients with ulcerative colitis. Gut 1993;34:63-7.

14 Brook MG, Smith HR, Bannister BA, McConnell M, Chart H, Scotland SM, et al. Prospective study of verocytotoxin producing, enteroaggregative and diffusely adherent Escherichia coli in different diarrhoeal states. Epidemiol Infect 1994;112:63-7.

15 Sambrook J, Fritsch EF, Maniatis T. Molecular cloning. A laboratory manual. New York: Cold Spring Harbor Laboratory Press, 1989.

16 Willshaw GA, Smith HR, Scotland SM, Field AM, Rowe B. Heterogeneity of Escherichia coli phages encoding vero cytotoxins: comparison of clone sequences determining VT1 and VT2 and development of specific gene probes. $\mathcal{f}$ Gen Microbiol 1987;133:1309-17.

17 Bilge SS, Clausen CR, Lau W, Moseley SL. Molecular characterization of a fimbrial adhesin, F1845, mediating diffuse adherence of diarrhea-associated Escherichia coli to HEp-2 cells. F Bacteriol 1989;171:4281-9.

18 Baudry B, Savarino SJ, Vial P, Kaper JB, Levine MM. A sensitive and specific DNA probe to identify enteroaggregative Escherichia coli, a recently discovered diarrheal pathogen. $\mathcal{F}$ Infect Dis 1990;161:1249-51.

19 Jerse EA, Yu J, Tall BD, Kaper JB. A genetic locus of enteropathogenic Escherichia coli necessary for the production of attaching and effacing lesions on tissue culture cells. Proc Natl Acad Sci USA 1990;87:7839-43.

20 Baudry B. Localization of plasmid loci necessary for the Baudry B. Localization of plasmid loci necessary for the
entry of Shigella flexneri into HeLa cells, and characterizaentry of Shigella flexneri into HeLa cells, and characteriza-
tion of one locus encoding four immunogenic polypeption of one locus encoding four immun
tides. F Gen Microbiol 1987;133:3403-13.

21 Le Bouguenec C, Archambaud M, Labigne A. Rapid and specific detection of the pap, afa, and sfa adhesin-encoding operons in uropathogenic Escherichia coli strains by polymerase chain reaction. $\mathcal{F}$ Clin Microbiol 1992;30:118993.

22 Scotland SM, Smith HR, Said B, Willshaw GA, Cheasty T, Rowe B. Identification of enteropathogenic Escherichia coli isolated in Britain as enteroaggregative or as members of a subclass of attaching-and-effacing $E$. coli not hybridising with the EPEC adherence-factor probe. $f$ Med Microbiol 1991;35:278-83.

23 Versalovic J, Koeuth T, Lupski JR. Distribution of repetitive DNA sequences in eubacteria and application to fingerDNA sequences in eubacteria and application to fingerprinting of

24 Olusanya O, Steinruck H, Aleljung P, Ascencio F, Curman B, Jarnerot G, et al. Surface properties, connective tissue protein binding and Shiga-like toxin production of Escherichia coli isolated from patients with ulcerative colitis. Int $\mathcal{F}$ Med Microbiol Virol Parasitol Infect Dis 1992;276 254-63.

25 Jallat C, Livrelli V, Darfeulille-Michaud A, Rich C, Joly B. Escherichia coli strains involved in diarrhea in France: high prevalence and heterogeneity of diffusely adhering strains. f Clin Microbiol 1993;31:2031-7. 
26 Garcia MI, Labigne A, Le Bouguenec C. Nucleotide sequence of the afimbrial-adhesin-encoding afa-3 gene cluster and its translocation via flanking IS1 insertion sequences. F Bacteriol 1994;176:7601-13.

27 Nowicki B, Labigne A, Moseley S, Hull R, Hull S, Moulds $J$. The Dr hemagrlutinin, afimbrial adhesins AFA-I and AFA-III, and F1845 fimbriae of uropathonic and dire diarrhea-associated Escherichia coli belong to a family of hemagglutinins with Dr receptor recognition. Infect Immun 8 No0,58:279-81

Nowick B, Truong L, Moulds J, Hull R. Presence of the D receptor in normal human tissues and its possible role in the pathogenesis of ascending urinary tract infection. $A m \mathcal{F}$ Pathol 1988;133:1-4.

29 Wold AE, Thorssen M, Hull S, Svanborg-Eden C. Attachment of Escherichia coli via mannose- or Gala 14Galb-containing receptors to human colonic epithelial cells. Infect Immun 1988;56:2531-7.

30 Smith CJ, Kaper JB, Mack DR. Intestinal mucin inhibits adhesion of human enteropathogenic Escherichia coli to HEp-2 cells. F Pediatr Gastroenterol Nutr 1995;21:269-76.

31 Adlerberth I, Hanson LA, Svanborg C, Svennerholm AM Nordgren S, Wold AE. Adhesins of Escherichia coli associated with extra-intestinal pathogenicity confer binding to colonic epithelial cells. Microb Pathogen 1995;18:373-85.

32 Bhan MK, Raj P, Levine MM, Kaper JB, Bhandari N, Srivastava $\mathrm{R}$, et al. Enteroaggregative Escherichia coli asso- ciated with persistent diarrhea in a cohort of rural children in India. F Infect Dis 1989;159:1061-4.

33 Cravioto A, Tello A, Navarro A, Ruiz J, Villafan H, Uribe F, et al. Association of Escherichia coli HEp-2 adherence patterns with type and duration of diarrhea. Lancet 1991;337: 262-3.

34 Gunzburg ST, Chang BJ, Elliott SJ, Burke V, Gracey M. Diffuse and enteroaggregative patterns of adherence of enteric Escherichia coli isolated from aboriginal children from the Kimberley Region of Western Australia. $\mathcal{F}$ Infect Dis 1993;167:7555-8.

35 Marques LRM, Abe CM, Griffin PM, Gomes TAT. Association between alpha-hemolysin production and HeLa celldetaching activity in fecal isolates of Escherichia coli. 7 Clin Microbiol 1995;33:2707-9.

36 Westerlund B, Korhonen TK. Bacterial proteins binding to the mammalian extracellular matrix. Mol Microbiol 1993;9: 687-94.

37 Agace W, Hedges S, Andersson U, Andersson J, Ceska M Svanborg C. Selective cytokine production by epithelial cells following exposure to Escherichia coli. Infect Immun 1993;61:602-9.

38 McCormick BA, Colgan SP, Delp-Archer C, Miller SI Madara JL. Salmonella typhimurium attachment to human intestinal epithelial monolayers: transcellular signalling to subepithelial neutrophils. $\mathcal{F}$ Cell Biol 1993;123:895-907. 